\title{
Monika KWIEcień
}

Uniwersytet Warszawski (Warszawa, Polska)

\section{Oficjalizmy jako środek leksykalno-stylistycznej modernizacji przekładu biblijnego (na-przykładzie Ewangelii Marka w Ekumenicznym Przekładzie Przyjaciół)}

\section{Prezentacja analizowanego przekładu}

Przedmiotem analizy oficjalizmów jako źródła stylistycznej modernizacji współczesnego stylu translacji biblijnych jest Ewangelia według św. Marka w tłumaczeniu nieoficjalnego zespołu ekumenicznego, który tworzą: prawosławny abp Jeremiasz Jan Anchimiuk, pastor Mieczysław Kwiecień oraz dwaj katolicy ks. Michał Czajkowski i Jan Turnau.

Ewangelia Marka była pierwszą księgą nowotestamentową przełożoną przez to grono. Dla odróżnienia się od późniejszej o kilkanaście lat inicjatywy oficjalnego przekładu ekumenicznego, podjętego z inspiracji Towarzystwa Biblijnego w Polsce, tłumacze nadali swojemu przedsięwzięciu nazwę: Ekumeniczny Przekład Przyjaciół.

Ewangelię Marka thumaczono w latach 1982-1984, ale wydano ją dopiero w 1993 roku. Ponieważ w roku 2012 ukazał się przekład całego Nowego Testamentu, przedmiotem analizy jest wersja Ewangelii Marka w nim zawarta, ponieważ w tej edycji wprowadzono ważne zmiany leksykalne (dalej skrót: Mk EPP).

Jak czytamy we wstępie do I wydania, tłumacze dążyli do tego, by przekład „operował językiem współczesnym, co nie znaczy nowoczesnym, co nie znaczy, że jakimś dziennikarskim żargonem. (...) Staraliśmy się o maksymalną wierność oryginałowi, nawet tam, gdzie dosłowne tłumaczenie jest dla niektórych szokujące. (...) Nie uważamy, by tego rodzaju rozwiązania były jedynie słuszne, sądzimy jednak, że wzbogacają wiedzę o tekście Biblii, oddzielonym od czytelnika barierą językową" (Turnau 1993: 4-5, wyróżnienie autora - M. K.).

Co zaś tyczy się odbioru tej translacji przez czytelników, warto przytoczyć informację następującą: „Ewangelia św. Marka (dwa wydania w łącznym nakładzie 9 tys. egzemplarzy) wzbudziła żywe reakcje w kręgach młodzieży z różnych Kościołów chrześcijańskich oraz - co było dużym zaskoczeniem - wśród zakonnic katolickich prowadzących pracę katechetyczną w szkołach średnich" (Kwiecień 2013: 188). 


\section{Oficjalizmy w Ewangelii Marka EPP}

Styl urzędowo-administracyjny jako jedna $\mathrm{z}$ odmian funkcjonalnych polszczyzny doczekał się wielu opracowań, w których omówiono także jego przemiany i wewnętrzne zróżnicowanie ${ }^{1}$. Liczne są również prace poświęcone polskiemu stylowi biblijnemu, a zwłaszcza ocenie środków językowych, wykorzystywanych do jego leksykalno-stylistycznej modernizacji w różnorodnych - oficjalnych i prywatnych - translacjach z końca XX i początków XXI stulecia.

W prywatnym ekumenicznym thumaczeniu Ewangelii według św. Marka znalazło się kilkanaście wyrazów i zwrotów, które należą do stylu urzędowo-administracyjnego. Ponieważ słownictwo z tego rejestru językowego zaczęło się szerzyć we współczesnych przekładach biblijnych, warto przyjrzeć się zasadności użycia tych oficjalizmów. W tekście Mk EPP pełnią one różne funkcje - z dobrym lub niedobrym skutkiem.

W prezentowanej tu analizie punkt odniesienia stanowią trzy oficjalne, konfesyjne tłumaczenia Pisma Świętego, z którymi tłumacze porównywali swój tekst: Biblia Tysiąclecia (BT), Biblia Poznańska (BP) oraz Biblia Warszawska (BW).

Ciekawą propozycją przekładową jest słowo pełnomocnictwo, brzmiące może nieco zbyt współcześnie, innowacyjnie jednak nawiązujące do tłumaczeń tradycyjnych: „Nauczał bowiem jako obdarzony pełnomocnictwem, a nie jak znawcy Ksiąg” (Mk 1,22; BW, BP - „nauczał ich jako moc mający / z mocą”). Mniej nacechowany stylistycznie, a równie trafny byłby przekład: obdarzony autorytetem, komentarz ewangelisty dotyczy bowiem autorytetu mesjańskiego Jezusa.

Odważnie i współcześnie przetłumaczono fragment Mk 3,21: „Gdy to doszło do Jego rodziny, przyszli, aby Go ubezwłasnowolnić, mówiono bowiem: Zwariował!". Tłumacze biblijni przekładają to miejsce rozmaicie. BW thumaczy „pochwycić” i „odszedł od zmysłów”, BP - „powstrzymać” i „stracił rozum”, C. Miłosz - „uprowadzić” i „postradał rozum”, R. Brandstaetter - „obezwładnić” i „oszalał”, a filologiczny przekład interlinearny - „chwycić” i „doprowadził się do szału".

Tłumacze Mk EPP zdecydowali się na wybór terminu prawnego ubezwłasnowolnić, by unaocznić, jak dramatyczne kontrowersje budziło wystąpienie Jezusa. Przekład ten mówi nie o motywacji wewnętrznej Jego rodziny, lecz o reakcji na ferment wokół Jego osoby (przeciwną wykładnię ma Biblia Warszawsko-Praska, stąd też wyjątkowo łagodne upomnieć: „A gdy dowiedzieli się o tym Jego bliscy, poszli, żeby Go upomnieć. Mówili bowiem między sobą: Postradał zmysły”). Wyjaśnienie postępowania krewnych Jezusa jest w pozostałych thumaczeniach, poza wersją Brandstaettera, wyrażone oględnie (w mowie zależnej lub niezależnej), Mk EPP natomiast jak gdyby przytacza wprost potoczną, a więc tym drastyczniej brzmiącą opinię współczesnych o Jezusie. Brzmienie to jest najradykalniejsze ze

Wśród przeglądowych ujęć najnowszych można wymienić m.in. opracowania D. Zdunkiewicz-Jedynak (2008), M. Wojtak (2012), E. Malinowskiej (2013). 
wszystkich translacji również dlatego, że przełamuje konwencję mówienia o Jezusie w polskich przekładach biblijnych.

Dążeniem do znalezienia współczesnego „ekwiwalentu egzystencjalnego” można thumaczyć także obecność urzędowych zwrotów: wydać świadectwo zdrowia (,-- Idź prosto do kapłana, niech cię obejrzy, (...) aby ci wydano świadectwo zdrowia” - Mk 1,44) i analogicznie wydać świadectwo rozwodu („Mojżesz pozwolił odesłać żonę, wydając świadectwo rozwodu" - Mk 10,4). Są one w pewnej mierze uzasadnione mocą prawną orzeczenia, od którego zależało miejsce człowieka w ówczesnym społeczeństwie lub poza jego nawiasem. Inne translacje przekładają tu odpowiednio: „Idź pokaż się kapłanowi i złóż za swe oczyszczenie ofiarę, którą przepisał Mojżesz, na świadectwo dla nich" (BT, podobnie BW, BP) oraz „Mojżesz pozwolił napisać list rozwodowy” (BT, BW, BP; jest tu mowa o dokumencie zwanym get, zob. Borzymińska, Żebrowski, red. 2003 2: 446). Biurokratyczne innowacje Mk EPP wprowadzają jednak dysonans stylistyczny świadectwo zdrowia uruchamia skojarzenia z ksiażeczka lub karta zdrowia.

Oficjalizmy takie jak aresztować (,Próbowali Go aresztować, lecz bali się ludu" - Mk 12,12) pojawiają się obok tradycyjnego pojmać, podobnie jak składać fałszywe zeznania (,Wprawdzie wielu składało przeciwko Niemu fałszywe zeznania, jednak niezgodne ze sobą" - Mk 14,56) obok fatszywie świadczyć. Oboczność ta ma związek z unikaniem powtórzeń, są to więc formy możliwe do przyjęcia.

Uzasadnione stylistycznie kontekstem wypowiedzi są oficjalizmy: upoważnić - w ustach przeciwników Jezusa z grona elity prawno-religijnej w scenie konfrontacji na dziedzińcu świątyni (,-- Jakim prawem czynisz to wszystko? Kto cię do tego upoważnił?" - Mk 11,28), stawiać zarzuty - w przesłuchaniu Jezusa przez arcykapłana (,-- Dlaczego w ogóle nie odpowiadasz na zarzuty, jakie ci się stawia?" - Mk 14,60) czy domagać się ułaskawienia - w narracji o sądzie u Piłata („Ale przedniejsi kapłani podmówili tłum, by domagał się raczej ułaskawienia Barabasza" - Mk 15,11). Zbędny jest natomiast zwrot zwrócić się z zapytaniem („Piłat zwrócił się do nich z zapytaniem: - Cóż więc [mam począ́c] z tym, [którego nazywacie] królem Żydów?” - Mk 15,22).

Użycie formy analitycznej odbyć naradę zamiast naradzać się współbrzmi z jawnym, oficjalnym charakterem zgromadzenia w odróżnieniu od spiskowania w kameralnym gronie (,Zaraz rano arcykapłani odbyli naradę ze starszymi, uczonymi i z całym Sanhedrynem" - Mk 15,1).

Wprowadzenie analitycznej formy dokonać uzdrowienia wynika z kolei z przesunięcia semantycznego w przekładzie Mk 3,2. BT tłumaczy następująco: „A śledzili Go, czy uzdrowi go w szabat, żeby Go oskarżyć” (w poprzednim zdaniu jest mowa o człowieku „,Z uschłą ręką”). Mk EPP przekłada zaś: „Żeby móc oskarżyć Jezusa, szpiegowano, czy dokona uzdrowienia w szabat"”. Nie tylko

Na marginesie rozważań poświęconych oficjalizmom można poczynić spostrzeżenie, że charakterystyczne dla thumaczenia Mk EPP dążenie do dynamizacji wypowiedzi sprawiło, iż 
przestawieniem kolejności członów zdania podkreślono tu, że przeciwnicy chcą jedynie przyłapać Jezusa na łamaniu przepisów religijnych - kaleki człowiek znika z pola widzenia, nie liczy się wcale. Uwydatnia to kontrast z postawą Jezusa, który swoimi pytaniami dotyka sedna problemu: „,- Godzi się w szabat dobrze czy źle czynić? Uratować człowieka czy zabić?” (w. 4).

Formy analitycznej w zdaniu podrzędnym ,czy dokona uzdrowienia w szabat" nie można zastąpić syntetyczną, bo ta ostatnia wymaga obligatoryjnie wyrażonego dopełnienia. Dodatkowo thumaczom udało się uniknąć częstego powtarzania zaimka Go / go (trzykrotnie w BT i BW, gdzie ponadto nie ma rozróżnienia pisowni; w BP zredukowano liczbę zaimków do dwóch: „I podpatrywali, czy uzdrowi go w szabat, aby Go oskarżyć").

W tłumaczeniu słów Jezusa w Mk 3,27 razi natomiast zwrot dokonać rabunku, kojarzący się z policyjnym żargonem: „Tak samo nikt nie zdoła, włamawszy się do domu mocarza, dokonać rabunku, chyba że go najpierw zwiąże i wtedy dopiero obrabuje"). Nieudany jest też zwrot spetniać wolę Boga, który powinien brzmieć wypetniać wole Boga (,Ktokolwiek bowiem spełnia wolę Boga, ten jest mi bratem, siostrą i matką" - Mk 3,35). Brzmienie to wprowadzono zapewne za BT (petnić wolę Boga jak oficjalizm petnić funkcję), bo BW i BP mają: czynić wolę Boga.

Bezkrytyczne użycie czasowników udać się zamiast pójść i oddalić się zamiast odejść grozi wywołaniem efektu komicznego. W zakończeniu perykopy o Ostatniej Wieczerzy czytamy: „Odśpiewawszy psalmy, udali się w kierunku Góry Oliwnej” (Mk 14,26). Wyjątkiem jest determinacja Józefa z Arymatei: „dostojny radca Sanhedrynu (...) udał się śmiało do samego Piłata i poprosił o wydanie ciała Jezusa" (Mk 15,43). Odnotujmy przy okazji wprowadzenie zaimka określającego sam. Zaimek ten uwydatnia szczególne znaczenie osoby, której dotyczy, wyeksponowanie rangi Piłata podkreśla więc jednocześnie siłę motywacji i zdecydowanie Józefa (BT: „Śmiało udał się do Piłata”; BW: „śmiało wszedł do Piłata”; PB: „poszedł odważnie do Piłata”).

Chcąc odróżnić brzmienie własnego przekładu od innych, tłumacze wybierają czasem rozwiązania nieudane. Należy do nich czasownik napiętnować (zamiast tradycyjnego zganić): „Wreszcie ukazał się Jedenastu spoczywającym przy stole i napiętnował ich niedowiarstwo i twardość serca (...)" (Mk 16,40). Podobnie ocenić można użycie czasownika upamiętnić, który występuje w akcentowanej pozycji finalnej i psuje bardzo udany przekład słów Jezusa: „,- Amen, powiadam wam: w każdym zakątku ziemi, dokądkolwiek dotrze Ewangelia, opowiadać będą także o tym, co ona uczyniła, aby ją upamiętnié” (Mk 14,9).

Oficjalizmem jest również zwrot zdać sprawę w narracji o apostołach, których Jezus rozesłał, powierzając im misję: „Apostołowie zeszli się do Jezusa i zdali sprawę z wszystkiego, co czynili i czego nauczali” (Mk 6,30; błąd składniowy, po-

ucięte zostały implikowane składniowo człony tak przełożonego zdania: „Żeby móc oskarżyć Jezusa, szpiegowano [domyślnie: Go, by przekonać się], czy dokona uzdrowienia w szabat”. 
winno być „zeszli się u Jezusa”). W BT tekst ten brzmi: „Wtedy Apostołowie zebrali się u Jezusa i opowiedzieli Mu wszystko, co zdziałali (sic!) i czego nauczali”. BW rytmizuje frazę orzeczeniami w pozycji anaforycznej i respektuje tradycyjny styl kai: „I zeszli się apostołowie u Jezusa, i opowiedzieli mu wszystko, co uczynili i czego nauczali". Neutralny stylistycznie jest przekład tego miejsca w BP.

Ponieważ była to misja, zrelacjonowanie jej przebiegu i skutków - czyli zdanie sprawy - jest thumaczeniem adekwatnym semantycznie. Niepokoi jednak skłonność tłumaczy do używania stylu oficjalnego, granicząca z nadużywaniem go, tym bardziej że w tym zdaniu występuje też czasownik czynili (zamiast neutralnego zrobili jak w BP lub uroczystego uczynili jak w BW).

Przejawem obecności stylu urzędowego jest także zwrot przywołać do po$r z a d k u$ w scenie bardzo ważnej ze względu na kontekst teologiczny, ostrą ripostę Jezusa poprzedza bowiem chrystologiczne wyznanie wiary apostoła Piotra. BW i BT używają tu dwóch czasowników: słabszego upomnieć (Piotr) i silniejszego zgromić (Jezus), BP odpowiednio - robić wymówki i skarcić. Tłumacze Mk EPP wybrali za tekstem greckim pełny paralelizm: „A Piotr, wziąwszy Go na bok, zaczął Go przywoływać do porządku. A On, odwróciwszy się, spojrzał na uczniów i przywołał do porządku Piotra, mówiąc: - Idź precz, szatanie! Albowiem nie myślisz o tym, co Boże, ale co ludzkie" (Mk 9,31-33). Można odnieść wrażenie, że odbiorcy nawykłemu do tradycyjnego brzmienia tekstu to innowacyjne thumaczenie przez ów paralelizm lepiej unaocznia dramatyczny rozziew między Piotrem a Jezusem.

Pomysłowym rozwiązaniem jest roślina uprawna w przypowieści o ziarnku gorczycy (w Mk EPP ładne skądinąd nasionko, co jednak stanowi niepotrzebną modyfikację tradycyjnego biblizmu). Roślina uprawna zastąpiła jarzyny, które ziarenko gorczycy przerasta w Biblii Brzeskiej oraz w Biblii Wujka, Biblii Gdańskiej, BT, BW i BP. Znaczenie tego słowa zmieniło się jednak, źródłosłów się zatarł (zostały w polszczyźnie tylko zboża ozime i jare oraz oziminy), więc jarzyny wydają się dzisiejszemu odbiorcy tekstu nie na miejscu. R. Brandstaetter proponuje zioła, Nowy Testament tzw. dynamiczny - ziele, A. Świderkówna - rośliny ogrodowe, Biblia Warszawsko-Praska i Biblia Paulińska - krzewy, a ks. T. Węcławski zastępuje jarzyny - warzywami. W Mk EPP natomiast „nasionko gorczycy (...) wyrasta na największą roślinę uprawną, o tak bujnych gałęziach, że ptaki niebieskie wija gniazda w ich cieniu" (Mk 4,32). Wyrażenie z języka urzędowego lub naukowego współistnieje tu w symbiozie z tradycyjnym biblizmem ptaki niebieskie.

\section{Wnioski}

Językowy kształt Ekumenicznego Przekładu Przyjaciół współbrzmi z przyjętym przez tłumaczy modelem odbioru Ewangelii, który za W. Jajdelskim można nazwać modelem egzystencjalnym. W myśl tego modelu ,przekaz biblijnej wiary 
nie ogranicza się do ustalonego raz repertuaru środków językowych, ale żywi się nieustannie wszystkim, co dociera w jego granice spoza dyskursu objawienia - z rozmaitych podsystemów społecznej komunikacji: oficjalnej i potocznej" (Jajdelski 2003: 180).

Przyjęcie takiego podejścia oznacza, że język biblijnej translacji nie musi odwoływać się wyłącznie do stylistyki wysokiej, używającej języka podniosłego jako jedynego stosownego sposobu wyrażania sacrum. Mówienie o rzeczywistości sakralnej, która przenika całą ludzką egzystencję, w naturalny sposób posiłkuje się językiem współczesnym i czerpie z różnych jego rejestrów. Oczywiście nie może to być bezrefleksyjna absorpcja, lecz świadome wybory translatorskie.

Poprzez dobieranie słownictwa spoza skonwencjonalizowanego zestawu leksyki biblijnej autorzy omawianego thumaczenia pragną także przerwać monotonię rutynowego odbioru, ożywić wrażliwość odbiorców, przytłumioną przez długotrwałe obcowanie z tekstem Pisma Świętego w jednym brzmieniu.

Ekumeniczny przekład Ewangelii według św. Marka modernizuje styl biblijny w duchu zasad określających kształt współczesnych tłumaczeń Pisma Świętego, zgodnie z ich pragmatyczną hierarchią ${ }^{3}$, podczas gdy w modelu tradycjonalistycznym na czoło wysuwa się kryterium wymagające zachowania powagi i dostojności godnej tekstu sakralnego. Mk EPP odwołuje się natomiast do podstawowej reguły dotyczącej thumaczenia Pisma Świętego, którą jest postulat przemawiania językiem współczesnym i zrozumiałym, a więc bliskim odbiorcy.

$\mathrm{W}$ thumaczeniu tym zdarzają się językowe usterki oraz nieudane propozycje przekładowe, między innymi chybione przypadki użycia oficjalizmów. Ponadto niektóre innowacje mogą zostać uznane - zwłaszcza przez odbiorców o konserwatywnych oczekiwaniach - za kontrowersyjne bądź niestosowne szczególnie w kontekście osoby Jezusa (np. termin prawny ubezwłasnowolnić, kolokwializmy w scenach egzorcyzmów: „wynoś się!”, „zostaw go!”, przytoczenie: „,-Zwariował!”).

Samo łączenie komponentów stylu biblijnego, będącego stylem wysokim, z wykładnikami stylów niskich i użytkowych uważa się tradycyjnie za podstawę do uznania tekstu za niespójny stylistycznie. Językoznawcy skłonni są zazwyczaj traktować każdy oficjalizm czy potocyzm jako naruszenie normy polszczyzny biblijnej $^{4}$ i świadectwo braku wyczucia językowego thumaczy ${ }^{5}$. Ekumeniczny prze-

E. Bieńkowska wymienia następujące zasady, które wyznaczają językowo-stylistyczny kształt współczesnych przekładów Pisma Świętego: 1) współczesność i komunikatywność języka, 2) wierność wobec oryginału, 3) poprawność językowa, 4) poszanowanie tradycji i zwyczaju polskiego języka biblijnego, 5) stosowność i godność słowa, 6) oryginalność i indywidualność (Bieńkowska 2002: 142-145).

4 E. Bieńkowska zwraca jednak uwagę na sięganie przez współczesnych tłumaczy po „nowe, odświeżające słownictwo do innych odmian stylowych polszczyzny (stylu potocznego, urzędowo-administracyjnego)" (Bieńkowska 2002: 143).

5 Zgodne uwagi krytyczne na temat językowej modernizacji translacji biblijnych za pośrednictwem oficjalizmów znaleźć można u wielu badaczy oceniających przemiany współczesnego stylu biblijnego. Wymieńmy tu dla przykładu analizy K. Długosz-Kurczabowej (1998), 
kład Ewangelii według św. Marka świadczy jednak o tym, że takie założenie jest niewłaściwe. Nie wystarczy też sporządzić listy form heterogenicznych wobec tradycji stylu biblijnego i odrzucanych automatycznie, bez sprawdzenia, w jakim celu i z jakim skutkiem je wprowadzono. Analiza kontekstów, w których słownictwo oficjalne pojawia się w Mk EPP, pokazuje bowiem, że pod warunkiem umiejętnego użycia elementy tego podsystemu językowego mogą być źródłem udanej modernizacji biblijnej polszczyzny.

\section{Bibliografia}

Bieńkowska D. (2002), Polski styl biblijny, Łódź.

Borzymińska Z., Żebrowski R. (red.) (2003), Polski słownik judaistyczny. Dzieje, kultura, religia, ludzie, tomy 1-2, Warszawa.

Długosz-Kurczabowa K. (1998), Charakterystyka językowa ekumenicznego przekładu „Ewangelii św. Mateusza”, „Przegląd Humanistyczny”, z. 4, s. 65-96.

Jajdelski W. (2003), Frazeologia w najnowszych przekładach Ewangelii wedlug św. Marka, „Rozprawy Komisji Językowej”, t. 29, Wrocław, s. 175-184.

Koziara S. (2005), Ekumeniczny przekład Nowego Testamentu (2001) w świetle tradycji polszczyzny biblijnej (zagadnienia wybrane), [w:] red. S. Mikołajczak, T. Węcławski, Język religijny dawniej i dziś. Materiały z konferencji Gniezno 3-5 czerwca 2004, tom 2, Poznań, s. 282-292.

Koziara S. (2009a), Frazeologia biblijna w języku polskim, Łask.

Koziara S. (2009b), Tradycyjne biblizmy a nowe polskie przektady Pisma Świętego (ujęcie filologiczno-normatywne), Kraków.

Kwiecień M. (2013), Abp Jeremiasz Jan Anchimiuk jako wspóttlumacz Nowego Testamentu (EPP), [w:] red. K. Wojciechowska, W. Konach, Ku Stowu - ku Kościołowi - ku światu. Księga Pamiątkowa dedykowana Arcybiskupowi Jeremiaszowi (Anchimiukowi) z okazji 70. urodzin, Warszawa, s. 187-196.

Malinowska E. (2013), Styl-dyskurs - komunikacja urzędowa, [w:] red. E. Malinowska, Nocoń J., Żydek-Bednarczuk U., Style współczesnej polszczyzny. Przewodnik po stylistyce polskiej, Kraków, s. 467-486.

Matuszczyk B. (2001), Czy zmierzch polskiego stylu biblijnego?, [w:] red. B. Zieliński, Język, literatura i kultura Stowian dawniej i dziś, Część 3 (część językoznawcza), Poznań, s. 209-219.

Matuszczyk B. (2003), O demetaforyzacji współczesnych przekładów Pisma świętego, [w:] red. R. Sokoloski, H. Duda, K. Klimkowski, Warsztaty translatorskie III, Lublin-Ottawa, s. 129-140.

Matuszczyk B. (2004), Dlaczego język współczesnych przekładów Pisma Św. nie jest piękny?, [w:] red. A. Tomecka-Mirek, Piękno materialne, piękno duchowe. Materiaty z konferencji 19 maja - 21 maja 2003 r., Łódź, s. 351-358.

Matuszczyk B. (2009), O potrzebie modernizacji języka religijnego w przekladach biblijnych, [w:] red. Koziara S., Przyczyna W., Polszczyzna biblijna między tradycją a współczesnością, t. 2, Tarnów, s. 51-58.

Szczepińska B. (1999), O słownictwie polskiego przektadu ekumenicznego Ewangelii św. Mateusza, [w:] Kreja B. (red.), Tysiąc lat polskiego stownictwa religijnego, Gdańsk, s. 223-252.

Szczepińska B. (2005), Ewangelie tylekroć tlumaczone... Studia o przekładach i przektadaniu, Gdańsk.

S. Koziary (2005, 2009a, 2009b), B. Matuszczyk (2001, 2002, 2003, 2009), B. Szczepińskiej $(1999,2005)$ i B. Walczaka (1999). 
Turnau J. (1993), Wspólny Marek, [w:] Ewangelia wedtug św. Marka. Przektad ekumeniczny, tłum. z języka greckiego: ks. Michał Czajkowski, abp Jeremiasz Jan Anchimiuk, pastor Mieczysław Kwiecień, Jan Turnau - sekretarz Zespołu, Warszawa.

Walczak B. (1999), W sprawie języka współczesnych przekładów Biblii, [w:] red. Z. Adamiak, S. Koziara, Od Biblii Wujka do wspótczesnego języka religijnego. Z okazji 400-lecia wydania Biblii ks. Jakuba Wujka, Tarnów, s. 79-85.

Wojtak M. (2012), Styl urzędowy, [w:] red. J. Bartmiński, Wspótczesny język polski, wyd. IV, Lublin, s. $155-171$.

Zdunkiewicz-Jedynak D. (2008), Wyktady ze stylistyki, Warszawa, s. 162-170.

\section{Wykorzystane tlumaczenia biblijne}

Biblia to jest Pismo Święte Starego i Nowego Testamentu. Nowy przekład z języków hebrajskiego i greckiego opracowany przez Komisję Przekładu Pisma Świętego (1975), Warszawa.

Brandstaetter R. (tłum.) (1980), Ewangelia wedlug Świętego Marka, Warszawa.

Czajkowski M., abp Jeremiasz Jan Anchimiuk, Kwiecień M., Turnau J. (tłum.) (2012), Ewangelia według św. Marka, [w:] Nowy Testament. Ekumeniczny Przekład Przyjaciół. Tłumaczenie z języka greckiego, Warszawa.

Węcławski T. (tłum.) (2004), Dobra nowina według św. Marka, Poznań.

Miłosz C. (tłum.) (1984), Ewangelia wedtug Marka, Apokalipsa, Paryż.

Świderkówna A. (tłum.) (1997), Ewangelia wedtug św. Marka, Kraków.

Popowski R. SDB (KUL), Wojciechowski M. (ATK) (tłum.) (1993), Grecko-polski Nowy Testament. Wydanie interlinearne z kodami gramatycznymi, Warszawa.

Nowy Testament. Najnowszy przekład z języków oryginalnych z komentarzem, Zespół Biblistów Polskich z inicjatywy Towarzystwa Świętego Pawła (opr.) (2008), Częstochowa.

Nowy Testament. Nowy przekład z języka greckiego na współczesny język polski (1991), Warszawa. Pismo Święte Starego i Nowego Testamentu w przekładzie z języków oryginalnych, zespół biblistów polskich z inicjatywy Benedyktynów Tynieckich (opr.) (1989), wyd. IV, Poznań-Warszawa.

Pismo Święte Starego i Nowego Testamentu w przekładzie z języków oryginalnych opracowat Kazimierz Romaniuk, Pierwszy Biskup Warszawsko-Praski (1997), Warszawa.

Pismo Święte Starego i Nowego Testamentu w przekladzie z języków oryginalnych ze wstepami i komentarzami, zespół pod redakcją ks. M. Petera (Stary Testament), ks. M. Wolniewicza (Nowy Testament) (1994), tom 3, Nowy Testament, Poznań.

\section{Monika Kwiecień}

\section{Elements of the official style as means for lexical and stylistic modernization of biblical translation - based on «The Gospel of Mark - private ecumenical translation»}

\section{Summary}

There are several words and phrases in the above mentioned private ecumenical translation of the Gospel of Mark (Mk EPP, 2012, $1^{\text {st }}$ ed. 1993) which are typical of the official style. Since the vocabulary characteristic of this style has started to spread in modern Polish biblical translations, checking its validity seems to be a worthwhile task for a linguist. 
Combining the lexical components of the biblical style, which is classified as the grand style, with elements of the low and plain styles is traditionally considered as an argument to deem such a text stylistically incoherent. Linguists used to treat any official or colloquial expression as violation of the stylistic norm of the Polish biblical language and as evidence of translators' stylistic incompetence. Nevertheless, the contextual analysis of the official vocabulary in the Mk EPP translation indicates that, if skillfully used, elements of the official style may be considered as means for successful modernization of the Polish biblical language. 